\title{
GAMBARAN SOSIAL MASYARAKAT DAN NILAI PENDIDIKAN DALAM NASKAH DRAMA SEMIDANG BUKIT KABU KARYA EMONG SOEWANDI
}

\author{
Ratu Anggraini ${ }^{1}$, Amrizal $^{2}$, Yayah Chanafiah ${ }^{3}$ \\ Universitas Bengkulu
}

Korespondensi: ratuanggraini14@gmail.com

\begin{abstract}
Abstrak
Tujuan penelitian ini untuk:(1) mengetahui tentang gambaran sosial masyarakat (2) nilai pendidikan apa saja yang terkandung dalam naskah drama Semidang Bukit Kabu karya Emong Soewandi. Penelitian ini menggunakan metode deskriptif kualitatif. Teknik analisis data dalam penelitian ini dengan menelaah teks-teks yang ada di dalam naskah drama Semidang Bukit Kabu karya Emong Soewandi. Dari hasil penelitian ini ditemukan (1) gambaran sosial masyarakat serawai baik dalam aspek tradisi, norma, simbol, mitos, sistem politik, situasi ekonomi, situasi sosial. Gambaran sosial masyarakat dalam naskah drama Semidang Bukit Kabu menjelaskan tentang kerusakan lingkungan yang diakibatkan oleh ulah manusia. (2) nilai-nilai pendidikan yang terkandung dalam naskah drama seperti nilai religius, jujur, toleransi, disiplin, kerja keras, kreatif, demokratis, rasa ingin tahu, cinta tanah air, cinta damai,dan nilai tanggung jawab.
\end{abstract}

Kata kunci: Gambaran sosial masyarakat, nilai pendidikan dalam naskah drama.

\begin{abstract}
The purpose of this study is to: (1) find out the social description of the People (2) Education Value in the Semidang Bukit Kabu Drama Script by Emong Soewandi. This study used descriptive qualitative method. Data analysis techniques in this study examined the texts in the Semidang Bukit Kabu drama script by Emong Soewandi. From the results of this research, it was found (1) there are the social description of the Serawai people in some aspects of tradition, norms, symbols, myths, political systems, economic situations, social situations. The social description of the people in the Semidang Bukit Kabu drama script explained that the environmental disaster caused by human. (2) educational values contained in drama scripts such as religious, honesty, tolerance, discipline, hard work, creativity, democratization, curiosity, love of the motherland, love of peace, and responsibility.
\end{abstract}

Keywords: Social picture of the community, the value of education in drama scripts.

\section{PENDAHULUAN}

Karya sastra merupakan sarana ekspresi yang di dalamnya terkandung nilai-nilai untuk disampaikan kepada penikmat karya sastra. Karya sastra juga berfungsi untuk menyampaikan ide-ide berupa kritik, sosial, politik, budaya dan pertahanan keamanan berkaitan dengan permasalahan-permasalahan yang ada di sekitar tempat tinggalnya. Rene Wellek (1993:122) mengatakan bahwa, sastra dan masyarakat saling berhubungan sebagai potret kenyataan sosial yang membuktikan bahwa sastra mempunyai kemampuan merekam ciri-ciri zamannya. 
Karya sastra dibagi menjadi dua yaitu, sastra lisan dan sastra tulis. Sastra lisan merupakan bentuk karya sastra berupa penuturan yang lahir dan mentradisi di suatu masyarakat, sedangkan karya tulis merupakan bentuk karya sastra yang menggunakan media tulisan. Salah satu jenis karya sastra tulis adalah naskah drama. Naskah drama adalah barang cetak atau naskah tertulis yang berbentuk dialog, menggambarkan watak seseorang dalam kehidupan, memiliki kesatuan dan berfungsi sebagai naskah sastra (untuk dibaca) maupun sebagai naskah untuk dipentaskan. (Emzir dkk, 2015: 261). Tidak semua karya sastra berupa naskah drama yang ditulis itu bersifat faktual melainkan, adanya gabungan antara faktual dan imajinasi pengarang seperti naskah drama daerah yang berjudul Semidang Bukit Kabu Karya Emong Soewandi. Naskah drama yang mengangkat ide tentang sastra daerah biasanya menggabungkan unsur budaya faktual yang berkembang di dalam masyarakat dengan imajinasi pengarang.

Penelitian ini berbeda dengan penelitian sebelumnya di mana penelitian ini berfokus pada gambaran sosial masyarakat dan nilai-nilai pendidikan yang terdapat dalam naskah drama. Naskah drama yang diteliti adalah salah satu karya sastra lokal yang berjudul Semidang Bukit Kabu karya Emong Soewandi yang bercerita tentang masyarakat serawai yang ada di Bengkulu Tengah.

Emong Soewandi adalah salah satu sastrawan yang pernah menempuh perguruan tinggi sebagai sarjana pendidikan dari Jurusan Bahasa dan Seni, FKIP Universitas Bengkulu. Beliau lahir di kota Curup, Provinsi Bengkulu. Beliau juga pernah menulis esai, puisi dan naskah drama, serta sutradara untuk berbagai pementasan teater. Beliau juga menulis esai dan makalah dipersipkan untuk seminar dan simposium sastra/budaya di Palembang, Lampung, Riau, Bogor dan Bengkulu. Puisi-puisi yang telah beliau terbaitkan antara lain, Antologi Riak, antologi penyair Bengkulu (Forum Sastra Bengkulu, 1994), Antologi Fragmentasi Diam (Taman Budaya Bengkulu, 1994), Antologi Kabar Duka Citaku (Bahtera, 1996), Antologi Sumatera Disastra, antologi puisi-puisi penyair Sumatera (Taman Budaya Bengkulu, 2005), Antologi Laut Berkabar, antologi puisi penyair Sumatera (Taman Budaya Riau, 2007) dan antologi terakhir, terbit 20012 adalah antologi Kamala yang diterbitkan di Malaysia, dalam rangka hari ulang tahun Penyair Negara Dato' Ahmad Kamal Abdullah. Beliau juga sempat menerima beasiswa prestasi dari kemendikbud untuk penulisan naskah drama tahun 2012. Beliau juga merupakan pendiri sebuah sanggar teater yang dikenal dengan sanggar Teater Petak Rumbia. Tak hanya namanya dikenal di masyarakat Bengkulu sastrawan ini juga dikenal di luar wilayah Bengkulu (Emong Soewandi, 2017:70).

Pada naskah drama Semidang Bukit Kabu karya Emong Soewandi ini, diungkapkan bahwa naskah drama ini mengangkat tentang gambaran sosial masyarakat Serawai akan mampu memberikan pelajaran-pelajaran yang bersifat edukatif serta pemahaman masyarakat tentang situasi dan kondisi yang terjadi pada masyarakat serawai pada waktu itu melalui sebuah naskah drama yang berjudul Semidang Bukit Kabu agar nantinya masyarakat bersikap lebih menghargai alam dan seisinya. Nilai-nilai pendidikan biasanya hanya akan kita peroleh dengan membaca dan memahami buku pelajaran atau buku motivasi, namun dengan adanya naskah drama ini jusru lebih menarik karena terdapat juga nilai-nilai pendidikan. Nilai-nilai pendidikan ini mampu mengungkapkan hal-hal yang memberikan arti sebuah perubahan hidup menjadi lebih baik kepada pembacanya. 
Semidang Bukit Kabu karya Emong Soewandi merupakan naskah drama yang mengisahkan tentang permusuhan antara manusia dan harimau yang terjadi pada masyarakat Serawai yang ada di daerah Kabupaten Bengkulu Tengah. Serta kerusakan alam dan keserakahan mastarakat serawai.

Hancurnya beberapa desa di Semidang Bukit Kabu ini dilatarbelakangi adanya dendam antara kaum harimau yang disebut dengan Ninik (nenek) dengan sekelompok manusia yang pernah melanggar batas antara manusia dan harimau. Dalam naskah ini terjadi tragedi pembunuhan seekor harimau betina yang dibunuh secara kejam oleh masyarakat Semidang Bukit Kabu. Prahara akan dendam tersebut menjadi kisah tragis penyerangan harimau terhadapat masyarakat Semidang Bukit Kabu.

Naskah drama Semidang Bukit Kabu karya Emong Soewandi menggambarkan nilai dan gambaran sosial kehidupan masyarakat Serawai baik dari segi sosial, ekonomi, bahasa, kepercayaan, dan lain-lain. Dengan adanya penelitian ini maka diharapkan siswa siswi dapat mengambil pelajaran dari kebudayaan lokal daerah setempat. Pada kurikulum 2013 menekankan pada aspek prilaku yang berarti pendidikan moral sangat ditekankan dalam kegiatan pembelajaran.

Oleh karena itu peneliti menyusun penelitian ini dengan judul

" Gambaran Sosial Masyarakat dan Nilai Pendidikan dalam Naskah Drama Semidang Bukit Kabu Karya Emong Soewandi “, dengan menggunakan pendekatan sosiologi sastra.

Teori yang digunakan dalam penelitin ini berupa :

1. Naskah Drama Sebagai Karya Sastra

Naskah drama adalah teks tertulis, sedangkan drama adalah cerita yang dilukiskan dalam gerak yang berisi doalog-dialog antar tokoh. Kata drama berasal dari bahasa Yunani “ draomai” yang berarti berbuat, bertindak, atau beraksi. Sebagai salah satu genre sastra, naskah drama dibangun oleh struktur fisik (kebahasaan) dan struktur batin (semantik,makna). Wujud fisik sebuah naskah adalah dialoq atau ragam tutur. Bentuk naskah drama dan susunannya berbeda dengan naskah cerita pendek atau novel. Naskah drama tidak mengisahkan cerita secara langsung. Penuturan ceritanya diganti dengan dialog para tokoh, dari pembicaraan para tokoh itu penonton dapat menangkap dan mengerti seluruh dari ceritanya. (Luxemburg dalam Wiyatmi, 2005:43).

Adapun struktur yang membangun naskah drama adalah :

1. Plot atau kerangka cerita

2. Penokohan dan perwatakan.

3. Dialog ( percakapan).

4. Setting/Landasan/Tempat Kejadian

5. Tema/Nada Dasar Cerita

6. Amanat/Pesan Pengarang

7. Petunjuk Teknis

2. Gambaran sosial masyarakat dalam karya sastra

Sastra menyajikan kehidupan, dan kehidupan sebagian besar terdiri dari kenyataan sosial. Walaupun karya sastra juga meniru alam dan dunia subjektif manusia. Sastra sering memiliki kaitan dengan institusi sosial tertentu. Sastra mempunyai fungsi sosial yang tidak sepenuhnya bersifat pribadi. Permasalahan studi sastra menyiratkan atau merupakan 
masalah social berupa: masalah tradisi, konvensi, norma, jenis sastra, simbol, dan mitos. Sastra dapat dikaitkan dengan situasi tertentu, atau dengan sistem politik, ekonomi, dan sosial tertentu. Penelitian dilakukan untuk menjabarkan pengaruh masyarakat terhadap sastra dan kedudukan sastra dalam masyarakat.

( Rene Wellek 1990: 109-110).

Peneliti menganalisis naskah drama Semidang Bukit Kabu karya Emong Soewandi dengan menggunakan sosiologi karya sastra mengenai gambaran sosial masyarakat Serawai. Sebagian besar masyarakat suku Serawai berdiam di Kabupaten Bengkulu Selatan, yakni di Kecamatan Sukaraja, Talo, Pino, Kelutum, Manna, dan Seginim. Saat ini banyak dari masyarakat suku Serawai yang merantau ke daerah-daerah lain seperti, Kepahyang, Bengkulu Tengah, dan Bengkulu Utara. Sebagian besar masyarakat Serawai hidup sebagai petani, khususnya perkebunan. Masyarakat suku Serawai mempunyai suatu kesenian tradisional yang sampai sekarang tetap utuh walaupun dipengaruhi arus zaman serba modern. Kesenian tersebut tetap disenangi oleh masyarakat suku Serawai, mereka memelihara kesenian leluhurnya supaya tetap utuh. Tentu saja mereka beranggapan, bahwa tidak ada seni yang mendarah daging. Begitu juga dengan tari yang telah mendarah daging. Begitu juga dengan tari andun yang merupakan tarian adat masyarakat Serawai.

Tari andun merupakan kesenian tradisional yang dimiliki oleh masyarakat Serawai pada umumnya. Tari andun merupakan bagian dari upacara perkawainan di suku Serawai pada acara bimbang adat atau bimbang ulu. Tari andun ditarikan oleh bujang dan gadis secara berpasangan, dengan satu syarat pasangan tersebut tidak mempunyai hubungan tali persaudaraan atau satu dusun (sekampung). Selain bujang dan gadis pada tari andun juga ditarikan oleh orang yang sudah berkeluarga, yaitu dengan cara tidak berpasangan. Pada saat beberapa orang yang sudah berkeluarga diperbolehkan untuk turut menari, begitu juga untuk mengiri penganten laki-laki yang sudah berkeluarga untuk ikut menari. Didalam tari andun ini juga terdapat kesenian yaitu rejung. Rejung merupakan suatu kesenian yang terdapat atau yang pelaksanaannya dilakukan ketika tari andun dilaksanakan. Musik pengiring tari andun diiringi oleh alat musik rebana dan kelintang dan masing-masing satu.

\section{Nilai Pendidikan}

Fraenkel (1977: 21) mengungkapkan bahwa, nilai adalah gagasan tentang sesuatu yang berharga, nilai adalah konsep, abstraksi. Nilai juga erat hubungannya dengan manusia, baik dalam bidang etika yang mengatur kehidupan sehari-hari manusia, maupun bidang estetika yang berhubungan dengan persoalan keindahan, bahkan nilai masuk ketika manusia memahami agama dan keyakinan beragama. Oleh karena itu nilai berhubungan dengan sikap seseorang sebagai warga masyarakat, warga suatu bangsa, sebagai pemeluk suatu agama, dan sebagai warga dunia.

Berikut nilai-nilai yang perlu dikembangkan dalam instansi pendidikan.

1. Nilai Religius

2. Jujur

3. Toleransi

4. Disiplin

5. Kerja Keras

6. Kreatif 
7. Demokratis

8. Rasa ingin tahu

9. Cinta tanah air

10. Cinta damai

11. Tanggung jawab

Berdasarkan latar belakang masalah di atas, maka rumusan masalah penelitian ini yaitu (1) Bagaimana gambaran sosial masyarakat Serawai dalam naskah drama Semidang Bukit Kabu karya Emong Soewandi (2) Bagaimana nilai-nilai pendidikan yang terkandung dalam naskah drama Semidang Bukit Kabu karya Emong Soewandi.

\section{METODE}

Metode yang digunakan dalam penelitian ini adalah metode penelitian deskriptif kulitatif. Data yang dihasilkan dalam penelitian ini adalah kutipan yang mengandung Gambaran Social Masyarakat dan Nilai Pendidikan dalam Naskah Drama Semidang Bukit Kabu karya Emong Soewandi. Sumber data dalam penelitian ini adalah naskah drama Semidang Bukit Kabu karya Emong Soewandi dengan jumlah halaman 27 halaman. Teknik pengumpulan data dalam penelitian ini adalah teknik studi pustaka. Studi kepustakaan berkaitan dengan kajian teoritis dan referensi lain yang berkaitan dengan nilai, budaya, dan norma yang berkembang pada situasi sosial yang diteliti. Teknik alanisis data yang digunakan adalah teknik contect analysis atau metode analisis isi yaitu, membaca naskah drama, mengidentifikasi data-data terkait, menganalisis unsur gambaran sosial masyarakat serta nilai-nilai pendidikan dan menyimpulkan.

\section{HASIL DAN PEMBAHASAN}

Naskah drama Semidang Bukit Kabu menceritakan tentang perjalanan penunjuk jalan, pengembara dan wanita ke Semidang Bukit Kabu. Mereka merasakan adanya suatu hal gaib yang sangat aneh di tempat tersebut bahkan mereka dijumpai oleh sekelompok sosok orang-orang hitam yang merupakan mahluk gaib penghuni Semidang Bukit Kabu.

Penunjuk jalan menceritakan bahwa di Semidang Bukit Kabu pernah hidup marga yang pernah dihabisi dan diserang oleh segerombolan sebie. Sebie adalah sebutan untuk harimau betina. Masyarakat serawai kerap memanggil harimau itu dengan sebutan sebei yang artinya nenek. Kejadian itu berawal dari perbuatan keji yang dilakukan oleh orang-orang kampung yang dipimpin oleh seseorang yang bernama Ginde. Ginde adalah kepala dusun yang dihormati oleh masyarakat Semidang Bukit Kabu. Suatu sekita Ginde dan orang-orang kampung berburu seekor harimau betina yang ternyata merupakan jelmaan mahluk gaib yang bernama Sembiyan. Nama Sembiyan berarti pelita dusun atau kembang desa yang merupakan gadis cantik jelmaan harimau. Setelah berhasil membunuh Sembiyan orang-orang kampung memotong leher harimau tersebut lalu

memancangkannya di gerbang dusun. Kulitnya diambil dan dijadikan gendang, jantungnya diambil untuk pesta di malam hari, dagingnya ditumbuk dan ditebarkan di jalanan dusun. Mereka beranggapan hal ini akan menjadi peringatan bagi semua mahluk bahwa manusia adalah penguasa. Bahwa tanah, air, ladang dan hutan adalah penjejakan manusia.

Sementara itu, orang-orang hitam yang merupakan jelmaan harimau gaib mengetahui perbuatan keji orang-orang kampung terhadap Sembiyan mereka sangat 
marah dan ingin membalas dendam. Lalu orang-orang hitam dipimpin wanita tua melakukan upacara dan membaca mantra untuk memanggil arwah Sembiyan agar mereka mengetahui kebenaaran yang telah terjadi di balik kematian Sembiyan. Setelah mengetahui bahwa Sembiyan benar-benar terbunuh oleh orang-orang kampung maka orang-orang hitam yang merupakan harimau gaib melakukan penyerangan ke Semidang Bukit Kabu.

Di sisi lain, kematian Sembiyan membawa kesedihan bagi seorang lelaki yang bernama Bentua. Bentua adalah seorang penyair sepi yang telah memelihara Sembiyan dari kecil. Sembiyan sejak itu selalu ingin bersama Bentua dan menjaganya. Namun Sembiyan datang menemui Bentua ketika bulan belum purnama. Tanpa memberikan tanda tujuh gaung suaranya dan tiga elang terbang rendah sehingga Bentua tidak mengetahui kedatangan Sembiyan. Karena hal tersebut Bentua sangat menyesal sebab ia telah membuat Sembiyan masuk dalam jebakan orang-orang kampung dan terbunuh.

\title{
Analisis Gambaran Sosial Masyarakat Semidang Bukit Kabu
}

Pada naskah drama Semidang Bukit Kabu sangat jelas menggambarkan tentang situasi dan kondisi masyarakat Serawai yang mengalami peristiwa dengan harimau. Gambaran sosial masyarakat Serawai dalam naskah drama ini dibuktikan dengan adanya tradisi, kepercayaan, norma, mitos, simbol, situasi politik, ekonomi dan sosial masyarakat.

a. Tradisi

Naskah drama Semidang Bukit Kabu merupakan karya sastra tulis yang menyiratkan tradisi masyarakat suku Serawai. Tradisi masyarakat suku Serawai berupa adat istiadat yaitu kesenian tari tradisional Tari Andun. Tari Andun merupakan bagian dari upacara perkawinan di suku Serawai. Musik pengiring Tari Andun diiringi oleh alat musik rebana dan kelintang atau canang masing-masing satu.

Pada naskah drama Semidang Bukit kabu terdapat pula tradisi yang berupa Rejung. Rejung merupakan sastra daerah yang dimiliki masyarakat serawai yang berupa nyanyian kesedihan dan kebahagian dilakukan pada saat kegiatan adat.

Pada adegan enam, terdapat gambaran tradisi masyarakat Serawai yang berupa rejung (irama ratapan) dan tarian andun.

\author{
Assalamu'alikum \\ Assalamu'alaikum \\ (disusul irama ratapan \\ kematian) \\ Bimillah di mule jadi \\ Bismillah di pangkeal kate \\ La kami kini besedih \\ Kate la lengit sudah abis di \\ tamat abis.
}

Orang-orang hitam sambil duduk
mengerakean tangannya dengan
gerakan andun. (Halaman 14)

Kutipan pertama merupakan salah satu bentuk rejung dalam bahasa Serawai. Dialog tersebut menggambarkan ratapan kesedihan orang-orang hitam atas kematian 
Sembiyan. Tradisi berejung dipimpin oleh satu orang yaitu wanita tua yang membaca mantra untuk memanggil arwah Sembiyan sedangkan orang-orang hitam bersenandung rejung Serawai dalam nada tinggi. Pada kutipan kedua menggambarkan adanya tarian andun yang ditarikan oleh tokoh orang-orang hitam ketika berejung untuk memanggil arwah Sembiyan. Tarian andun merupakan salah satu tarian tradisional masyarakat suku Serawai yang ditarikan biasanya dalam upacara penyambutan seorang tamu. Dalam naskah ini tarian tersebut digambaran untuk menyambut kedatangan arwah Sembiyan.

Berdasarkan kutipan-kutipan di atas tradisi masyarakat Serawai pada naskah drama Semidang Bukit Kabu masih sangat tergambarkan dengan kental berupa adat istiadat yang masyarakat Serawai gunakan, baik dari tarian tradisional maupun ritual-ritual yang masih dilakukan oleh masyarakat Serawai.

b. Konvensi Norma

Konvensi norma yang terdapat dalam naskah drama Semidang Bukit Kabu adalah mengenai adanya batasan antara alam manusia dengan alam gaib yaitu peraturanperaturan yang telah disepakati antara orang-orang kampung dan harimau gaib yang telah disepakati sejak dahulu.

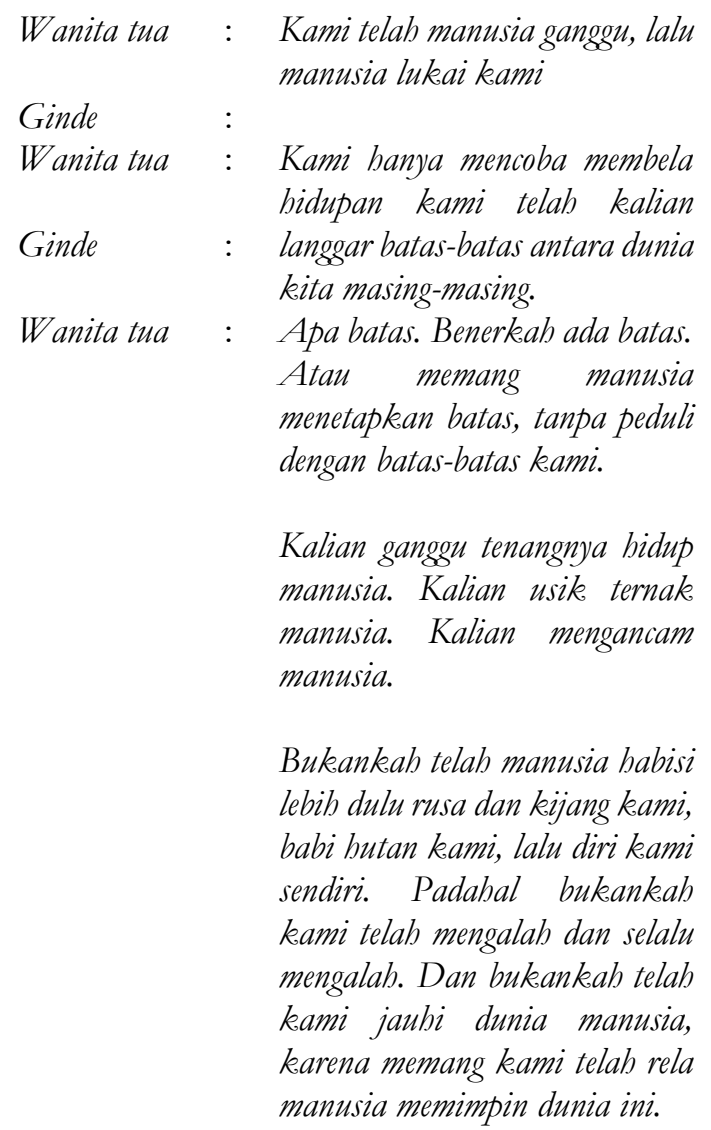

(Halaman 25)

Kutipan tersebut menyiratkan bahwa telah ada batasan-batasan kehidupan yang seharusnya disepakati oleh Ginde, wanita tua, serta manusia dan makhluk gaib. Kesepakatan ini berupa perjanjian bahwa manusia tidak boleh membunuh makhluk lain seperti binatang terlebih lagi tidak boleh membunuh makhluk lain dengan cara yang keji. Sebaliknya makhluk lainpun tidak dibenarkan untuk menganggu ketenangan manusia dan 


\section{Ratu Anggraini, Amrizal, Yayah Chanafiah}

mengusik ternak manusia. Perjanjian lainnya yang telah disepakati yaitu harimau harus menjauhi dunia manusia dan para harimau tersebut telah rela manusia memimpin dunia.

c. Simbol

Berikutnya akan dianalisis mengenai simbol-simbol sosial yang terdapat di dalam naskah drama Semidang Bukit Kabu. Hal ini ditemukan pada kutipan naskah drama Semidang Bukit Kabu adegan delapan.

$\begin{array}{ll}\text { Wanita } & \text { Pukul } \\ \text { bitam I } & \text { Canang! } \\ & \text { Berkumpulah semua! } \\ & \text { Bunyi canang atau gong dipukul } \\ & \text { dengan kencang berulang-ulang. } \\ & \text { Wanita berherak dengan cepat ke } \\ \text { Wanita! } & \text { tepi depan penonton dan para } \\ \text { bitam I } & \text { pemain lainnya lari ke bawab } \\ & \text { pangsung di depan penonton. } \\ & \text { Manusia! } \\ & \text { Manusia! } \\ & \text { Manusia! } \\ & \text { Dengar! } \\ & \text { Manusia simpan kata ini dalam } \\ & \text { dendammu! } \\ & \text { Dia telah membunubmu! } \\ & \text { Dia telah membunubmu! } \\ & \text { Kata ini tekah membunubmu! } \\ & \text { Manusia! } \\ & \text { Manusia! } \\ & \text { Terakan kata ini di } \\ & \text { pedangmu! Terakan kata } \\ & \text { ini disuaramu! } \\ & \text { Tulis kata ini di tenagamu! } \\ & \text { Ukur kata ini di cakarmu! } \\ & \text { Kata ini telah } \\ & \text { membunubmu! Manusia! } \\ & \text { Manusia! } \\ & \text { Manusia! } \\ & \text { Simpan kata ini dalam } \\ & \text { darabmu! Simpan kata ini dalam } \\ & \text { darabmu! Lalu } \\ & \text { bancurkan! } \\ & \text { Robobkan kesombongan } \\ & \text { kata! } \\ & \text { Kata ini telab begitu } \\ & \text { angkub! } \\ & \text { Kata ini adalah manusia! } \\ & \text { Manusia! Manusia! } \\ & \text { Manusia! }\end{array}$




\author{
Hancurkan manusia \\ sekarang! Kita bergerak \\ kesemidng bukit kabu! \\ Kita bergerak kesemidang \\ bukit kabu! \\ Semidang bukit kabu! \\ Semidang Bukit Kabu! \\ Semidang Bukit Kabu! \\ (Halaman 21)
}

Wanita hitam 1 dalam naskah drama Semidang Bukit Kabu merupakan tokoh yang memiliki status sosial tinggi dalam kaum harimau. Wanita hitam 1 bertindak sebagai pemimpin para kaum harimau gaib pada kutipan tersebut wainita hitam 1 memerintahkan untuk memukul canang atau gong sebagai tanda untuk para harimau gaib berkumpul. Kemudian bunyi canang yang dipukul berulang-ulang secara kencang memberikan tanda sebagai genderang perang para harimau gaib yang akan menyerang para manusia.

d. Mitos

Mitos merupakan cerita prosa rakyat mengisahkan serangkaian peristiwa nyata dan imajiner menyangkut asal-usul dan perubahan-perubahan alam raya dan dunia dewa-dewi, kekuatan-kekuatan atas kodrati manusia, pahlawan dan masyarakat. Mitos yang berkembang hingga sekarang yaitu cerita masyarakat Serawai tentang Semidang Bukit Kabu yang daerahnya hingga sekarang ditutup dan menjadi hutan lindung yang ada di Kabupaten Bengkulu Tengah, sehingga diangkatlah menjadi sebuah naskah drama. Dalam naskah drama Semidang Bukit Kabu terdapat pada adegan 1 naskah drama Semidang Bukit Kabu terdapat percakapan antara pengembara, penunjuk jalan, dan wanita tentang keberadaan suatu tempat yang bernama Semidang Bukit Kabu. Hal tersebut dapat dilihat pada kutipan berikut.

$\begin{array}{ll}\text { Pengembara } & \text { Semidang Bukit } \\ & \text { Kabu? } \\ & \text { Aku pernah } \\ \text { Penunjuk.jalan : } & \text { mendengar nama } \\ & \text { itu. } \\ & \text { Bukankah itu } \\ & \text { nama } \\ & \text { sebuah magra } \\ & \text { yang diserang dan } \\ & \text { dibabisi.... } \\ & \text { ne-nenek. } \\ & \text { Benarkah itu } \\ & \text { penunjuk jalan } \\ & \text { Coba } \\ & \text { Ceritakanlah } \\ & \text { pada kami } \\ \text { Pengembara } & \text { apa } \\ & \text { sebenarnyayang } \\ & \text { terjadi. }\end{array}$




$\begin{array}{cl} & \text { Nenek, apa } \\ & \text { nenek } \\ & \text { itu? } \\ \text { Petunjuk Jalan } & \text { Maksudku } \\ & : \text { ba...maksudku } \\ & \text { sebie, } \\ \text { Pengembara } & \text { ninik... } \\ & \text { maksudku } \\ & : \text { ha...ha... } \\ & \text { Maksudmu } \\ & \text { harimau kan? } \\ & \text { Ya, harimau. } \\ & \text { (Halaman 3) }\end{array}$

Kutipan tersebut memberikan gambaran adanya mitos yang berkembang di masyarakat tentang marga Semidang Bukit Kabu yang diserang dan dihabisi oleh segerombolan harimau. Berkembang pula mitos di kalangan masyarakat bahwa ada larangan untuk menyebutkan nama harimau tetapi kata tersebut diganti dengan nenek, ninik, atau sebei. Hal tersebut dikarenakan masyarakat masih kuat kepercayaannya terhadap mitos yang berkembang di kalangan mereka.

e. Sistem Politik

Sistem politik dalam sebuah karya sastra erat hubunganya dengan perspektif pengarang atau cara pandangnya terhadap karya sastra yang bersifat politik. Politik dan idiologi dalam sastra tidak hanya berorientasi pada politik pemerintahan saja, tapi juga dalam berbagai bidang. Contohnya di dalam naskah drama Semidang Bukit Kabu terdapat penggambaran sistem kepemimpinan dan starta sosial. Hal tersebut dapat dilihat dalam kutipan berikut.

\begin{tabular}{|c|c|}
\hline Ginde & : Lakukan cepat! \\
\hline Orang & : Tidak!! \\
\hline kampung 3 & $\begin{array}{l}\text { Kau sendiri saja } \\
\text { yang melakukannya } \\
\text { Aku yang }\end{array}$ \\
\hline Ginde & : memerintah! Cepat! \\
\hline
\end{tabular}

Pada kutipan tersebut menggambarkan bahwa Ginde merupakan pemimpin dari orang-orang kampung Semidang Bukit Kabu.Ginde memerintahkan orang-orang kampung untuk memotong leher harimau yang bernama Sembiyan tersebut.Meskipun orang-orang kampung tidak ingin melakukannya namun mereka terpaksa memenuhi permintaan Ginde dikarenakan rasa hormat mereka terhadap pemimpin.

f. Situasi Ekonomi

Selain sistem politik, dalam naskah drama Semidang Bukit Kabu terdapat gambaran situasi ekonomi masyarakat. Sebagian besar masyarakat Serawai mata pencaharian pokoknya ialah bercocok tanam di sawah dan ladang. Selain bertanam padi 
mereka banyak membuka kebun kopi dan cengkeh. Perairan sungai dan lautnya banyak menyediakan ikan dan hasil hutannya, kayu, rotan serta hewan sekalipun cukup menguntungkan kehidupan mereka. Dengan hasil alam yang diperoleh masyarakat mereka mampu menghasilkan penghasilan dan mempunyai ladang sendiri untuk bercocok tanam.

Aspek ini dapat dianalisis dari segi mata pencaharian masyarakat. Seperti yang terdapat dalam kutipan dalam naskah drama tersebut.

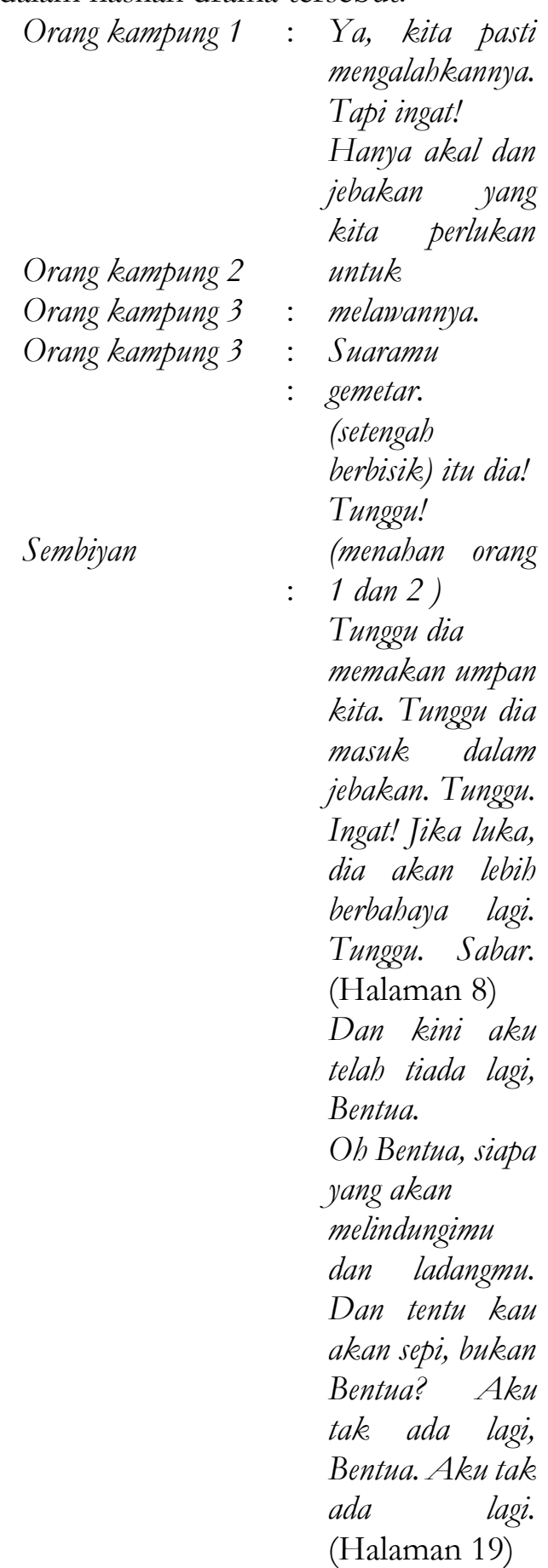


Pada kutipan di atas memberikan gambaran situasi ekonomi orang-orang kampung Semidang Bukit kabu yang memiliki mata pencaharian sebagai pemburu. Orang- orang kampung dan Ginde pergi ke hutan untuk memasang jebakan dan menangkap harimau.

Melalui dialog tokoh Sembiyan diperoleh gambaran bahwa tokoh bentua adalah seorang petani yang memiliki sebuah ladang yang cukup besar. Jadi dapat disimpulkan bahwa situasi ekonomi masyarakat Semidang Bukit Kabu dalam naskah tersebut memiliki mata pencaharian sebagai pemburu dan petani.

g. Situasi sosial

Masyarakat suku Serawai sebagian besar sebagai pekebun dan petani tak hanya berkebun masyarakat juga memanfaatkan hasil hutan untuk berburu hewan mencukupi kebutuhan sehari-hari mereka. Kegiatan berburu ini dilakukan masyarakat turun-temurun yang dilakukan menggunakan tombak. Tombak ialah alat berburu tradisional yang dibuat

Orang-orang bergerak mengelilingi menggunakan bambu tajam. Pada sembiyan dengan senjata siap naskah drama Semidang Bukit Kabu juga ditangan. (Halaman 9) tergambarkan situasi masyarakat Serawai saat berburu di hutan, akan tetapi yang diburu ini bukan kijang, rusa,dan kancil

melainkan harimau. Seperti dalam kutipan.

Orang-orang menyerang Sembiyan dengan serentak menusukkan tombak ke tububnya. Kecuali orang kampung 1 orang-orang serentak pula menarik. tombak, lalu mundur beberapa langkah dengan tetap bersiap.

Orang kampung menarik tombaknya dengan cepat.

Pada kutipan pertama di atas menggambarkan kondisi sosial masyarakat yang masih menggunakan tombak untuk berburu. Digambarkan dalam naskah drama Semidang Bukit Kabu masyarakat membunuh harimau dengan menusukkan tombak ke tubuh Sembiyan.

Wanita bitam I: Pukul canang!
Berkumpullah semua!
Bunyi canang atau gong dipukul dengan kencang
berulang-ulang. Wanita bergerak dengan cepat
ke tepi depan penonton dan para pemain lainnya
lari ke bawah panggung di depan
penonton.(Halaman 21)

Pada kutipan kedua mengambarkan situasi sosial masyarakat menggunakan alat tradisional berupa canang atau gong untuk mengumpulkan anggota masyarakat. Canang atau gong merupakan alat musik tradisional yang mengeluarkan bunyi yang digunakan pada saat upacara dan kegiatan adat setempat. Alat musik ini dibuat menggunakan logam dan kayu yang dimainkan satu sampai dua orang. Pada Naskah drama Semidang Bukit Kabu masih terdapat alat-alat tradisional yang menggambarkan situasi sosial masyarakat saat mengiringi upacara adat menggunakan alat musik canang atau gong. Wanita tua yang berperan sebagai pemimpin kaum orang-orang hitam memerintahkan beberapa orang 
hitam untuk memukul canang atau gong memberi petanda bahwa ada ritual yang akan mereka segera lakukan.

Masyarakat juga masih memiliki kepercayaan terhadap makhluk-makhluk gaib serta masih menggunakan pedupaan untuk memanggil para roh-roh leluhur yang mereka percayai. Pedupaan merupakan alat yang berisi bara api, kemenyan dan alat pendukung lainnya yang digunakan untuk melakukan ritual adat. Seperti dalam kutipan

\section{Wanita tua: Bawakan aku pedupaan. (Halaman 14)}

Tradisi Serawai dalam naskah drama ini digambarkan sangat jelas melalui dialog berbahasa Serawai. Bahkan terdapat juga rejung (senanjung ratapan) Serawai, mantra, pemikat (pemanis) yang diucapkan dalam bahasa Serawai. Berikut ini adalah salah satu contoh mantra dalam bahasa Serawai yang digunakan ketika perburuan harimau.

$\begin{array}{ll}\text { Orang } & \text { Ndah diade ndah keape. Bekujung } \\ \text { kampung } & \text { angin derudung bunging. Kelap tuape } \\ 2 & \text { debadapuyang. Sedie rupe-rupe bekujur. } \\ & \text { Ndab diade berure darah. Ndah keape } \\ & \text { dedie nyawa. Tetak. si belang sudabka } \\ & \text { sudah. Hak! Hak! Hak!! (Halaman }\end{array}$

8)

\section{Nilai Pendidikan}

Fraenkel (1977: 21) mengungkapkan bahwa, nilai adalah gagasan tentang sesuatu yang berharga, nilai pendidikan adalah konsep, abstraksi. Nilai juga erat hubungannya dengan manusia, baik dalam bidang etika yang mengatur kehidupan sehari-hari manusia, maupun bidang estetika yang berhubungan dengan persoalan keindahan, bahkan nilai masuk ketika manusia memahami agama dan keyakinan beragama. Oleh karena itu nilai berhubungan dengan sikap seseorang sebagai warga masyarakat, warga suatu bangsa, sebagai pemeluk suatu agama, dan sebagai warga dunia (Kama dan Encep, 2016: 18-19).

Dalam naskah drama Semidang Bukit Kabu karya Emong Soewandi juga banyak terdapat nilai pendidikan seperti nilai religious, jujur, toleransi, disiplin, kerja keras, kreatif, mandiri, demokratis, rasa ingin tahu, semangat kebangsaan, cinta tanah air, menghargai prestasi, bersahabat atau komunikatif, cinta damai, gemar membaca, peduli lingkungan, peduli sosial, dan tanggung jawab.

a. Niai Religius

Nilai religius yang dimaksut dalam naskah drama Semidang Bukit Kabu menyiratkan bahwa masyarakat Semidang Bukit Kabu masih percaya terhadap roh dan meyakini adanya kepercayaan terhadap roh tersebut dengan hal-hal yang berbau persembahan dengan memanggil arwah-arwah lewat sesajen atau pedupaan.

b. Jujur

Nilai jujur sangat penting diterapkan, dengan adanya sikap jujur yang dilakukan menimbulkan kepercayaan seseorang terhadap kita. Dalam naskah Semidang Bukit Kabu ini juga terdapat prilaku jujur yang menjadi upaya suara dirinya sebagai orang yang selalu dapat dipercaya dalam perkataan tindakan maupun pekerjaan. Menggambarkan bahwa dalam naskah drama Semidang Bukit Kabu karya Emong Soewandi terdapat nilai jujur yang dapat diaplikasikan dalam ranah pendidikan seperi dialog antara Sembiyan dengan Bentua, yang mana Sembiyan memberitahu Bentua bahwa Bentua harus meninggalkan Semidang Bukit Kabu untuk menyelamatkan dirinya. Sembiyan juga mengatakan dengan 
Bentua secara jujur bahwa dirinya telah mati dibunuh oleh orang kampung Semidang Bukit Kabu.

c. Toleransi

Sikap toleransi yang tergambarkan dalam naskah drama Semidang Bukit Kabu menghargai pendapat seseorang, terbukti melalui dialog antara petunjuk jalan, wanita, dan pengembara. Menggambarkan bahwa adanya tindakan toleransi yang dilakukan oleh petunjuk jalan saat mengantarkan para pejalan kaki untuk melakukan penelitian mereka tentang daerah Semidang Bukit Kabu. Petunjuk jalan mengatakan bahwa tidak ada jalan lain kita harus bermalam di sini dikarenakan terlalu berbahaya untuk melanjutkan perjalanan. Kemudian disambung dengan wanita yang bersepakat untuk mengikuti perkataan petunjuk jalan walaupun sebelumnya terjadi ketidak sepakatan antara mereka. Disini membuktikan bahwa adanya nilai toleransi dalam naskah Semidang Bukit Kabu.

d. Disiplin

Disiplin merupakan suatu tindakan yang menunjukkan prilaku tertib dan patuh pada berbagai ketentuan peraturan baik itu peraturan yang tertulis maupun peraturan yang tidak tertulis. Disiplin juga perlu dilakukan untuk menghargai sesama mahkluk hidup. Membuktikan nilai disiplin patuh terhadap perkataan seorang yang dianggap sebagai pemimpin. Dibuktikan dengan perkataan orang kampung 3 yang memerintahkan orang kampung 1 dan 2 untuk bersabar dan tidak tergesah-gesah membunuh Sembiyan. Disini adanya peraturan yang berlaku bahwa keputusan sepenuhnya ada di tangan pemimpin dan harus melakukan perintahnya.

e. Kerja Keras

Prilaku yang menunjukan upaya sungguh-sungguh dalam mengatasi berbagai hambatan dan tugas serta menyelesaikan tugas dengan sebaik-baiknya. Dalam naskah drama Semidang Bukit kabu juga menggambarkan suatu kerja keras yang dilakukan. Menunjukkan kerja keras yang dilakukan orang-orang hitam untuk mencari Ading Sembiyan yang telah mati terbunuh oleh orang-orang kampung. Mereka orang hitam tidak putus asa untuk mencari Sembiyan, mereka terus menyelusuri jalan untuk menemui Ading mereka Sembiyan.

f. Kreatif

Berfikir dan melakukan sesuatu untuk menghasilkan cara atau hasil baru dari sesuatu yang telah dimiliki. Dalam naskah drama Semidang Bukit Kabu ini ada sikap kreatif yang dilakukan oleh wanita terhadap penyair pada suatu tempat peristirahatan mereka yang mana wanita meminta penyair untuk memainkan gitar yang ada di tangan seorang penyair. Ide kreatif ini spontan muncul dari wanita.

g. Demokratis

Cara berfikir, bersikap, dan bertindak yang menilai sama hak dan kewajiban dirinya dan orang lain. Memperdulikan orang lain merupakan sikap orang yang demokratis, karena dengan adanya rasa peduli terhadap orang lain, berarti kita mempunyai hak dan kewajiban sama terhadap orang lain untuk saling membantu. Menjelaskan bahwa sikap demokratis Peduli terhadap orang lain disampaikan oleh Sembiyan yang peduli terhadap penyair, yang mana Sembiyan meminta Bentua untuk segera meninggalkan Semidang Bukit Kabu. Sembiyan melakukan itu karena dia tidak ingin adanya pertumpahan darah lagi yang terjadi di kawasan Semidang Bukit Kabu. 
h. Rasa ingin tahu

sikap dan tindakan yang selalu berupaya untuk mengetahui lebih mendalam dan meluas dari sesuatu yang dipelajarinya, dilihat, dan didengar. Menunjukakan sikap rasa ingin tahu yang mendalam dari wanita dan pengembara yang mana mereka ingin tahu prahara apa yang sesungguhnya telah terjadi di kawasan Semidang Bukit Kabu. Dengan sikap wanita yang terus memaksa penunjuk jalan untuk segera menceritakan kejadian apa yang sebenarnya terjadi.

i. Cinta tanah air

Cara berpikir, bersikap, dan berbuat yang menunjukkan kesetiaan,kepedulian dan penghargaan yang tinggi terhadap bahasa, lingkungan fisik, sosial, budaya, ekonomi, dan politik bangsa. Sikap cinta tanah air Ginde sebagai warga dusun dan sebagai pemimpin orang kampung bahwa manusialah yang berkuasa terhadap tanah, air, ladang dan hutan. Karena menurut Ginde hanya manusia yang berkuasa, akan tetapi pendapat Ginde itu salah, cinta tanah air yang dimaksud ialah bagaimana cara kita menghargai sesama ciptaan tuhan dan memeliharanya dengan baik tanpa menimbulkan kerusakan alam.

j. Cinta damai

Sikap, perkataan, dan tindakan yang menyebabkan orang lain merasa senang dan aman atas kehadiran dirinya. Adanya sikap damai yang di lakukan Ginde seseorang pemimpin orang kampung yang telah membunuh Sembiyan. Dia mengakui kesalahannya dan menyatakan untuk berdamai terhadap orang-orang hitam yang telah mengancamnya. Dengan ini adanya sikap cinta damai yang terdapat dalam naskah drama Semidang Bukit Kabu.

k. Tanggung jawab

Sikap dan prilaku seseorang untuk melaksanakan tugas dan kewajibannya, yang seharusnya dia lakukan, terhadap diri sendiri, masyarakat, lingkungan (alam, sosial dan budaya). Dalam naskah Semidang Bukit Kabu ini adanya sikap tanggung jawab terhadap perkerjaan yang dilakukan orang-orang kampung. Mereka diminta untuk memotong leher harimau betina yang bernama Sembiyan.

\section{PENUTUP}

\section{Kesimpulan}

Berdasarkan hasil analisis data mengenai Gambaran Sosial Masyarakat dan Nilai Pendidikan dalam Naskah Drama Semidang Bukit Kabu dapat disimpulkan bahwa dalam naskah drama ini tergambarkan mengenai kondisi masyarakat Serawai yang ada di 372eligio Semidang Bukit Kabu. Masyarakat Semidang Bukit Kabu 372eligiou besar sebagai petani dan pekebun kopi, akan tetapi tidak hanya berkebun saja masyarakat juga menggunakan hasil alam untuk berburu. Tradisi masyarakat Semidang bukit kabu mengenai adat istiadat masih sangat kental sekali, mereka masih percaya terhadap 372 eligio peraturan-peraturan kehidupan antara manusia dan makhluk-makhluk gaib. Dalam beberapa bagian kutipan naskah terdapat 372eligi-simbol seperti 372eligi canang untuk berkumpul dan pembakaran dupa sebagai suatu bentuk ritual adat.

Sedangkan nilai pendidikan yang dapat ditarik kesimpulannya dalam naskah drama ini antaranya, nilai 372 eligious, jujur, toleransi, disiplin, kerja keras, kreatif, demokratis, rasa ingin tahu, cinta tanah air, cinta damai, dan nilai tanggung jawab. Sebelas nilai pendidikan ini mampu memberikan wawasan pengetahui untuk kita masyarakat mampu lebih menghargai alam dan tidak untuk dirusak melainkan untuk dijaga dan 
dilestarikan keberadaannya. Nilai-nilai pendidikan ini dapat diaplikasikan dalam proses pembelajaran karya sastra di sekolah.

Saran

Penelitian ini diharapkan dapat memahami dan menambah wawasan atau pengetahuan mengenai gambaran sosial dan nilai pendidikan dalam naskah drama Semidang Bukit Kabu karya Emong Soewandi. Penulis juga berharap ada peneliti-peneliti yang akan mengenali dan mengkaji aspek lain, karena dalam naskah drama ini masih banyak aspek yang belum digali dan dikaji selain itu juga penulis berharap penelitian ini dapat bermanfaat bagi semua khususnya bagi dunia pendidikan. Bagi masyarakat peneliti berharap degan adanya penelitian ini mampu membuka pikiran masyarakat untuk saling menjaga lingkungan sekitar.

\section{DAFTAR PUSTAKA}

Emzir., dan Saifur Rohman. 2015. Teori dan Pengajaran Sastra. Jakarta: Rajawali Pers Endaswara, Suwardi. 2001. Metode Pembelajaran Drama: Apresiasi, Ekspresi, dan Pengajaran. Yogyakarta: KAPS

Faruk. 2012. Pengantar Sosiologi Sastra. Yogyakarta: Pustaka Pelajar.

Kama, AH dan Encep, SN. 2016. Metode internalisasi Nilai-Nilai. Bandung: Maulana Media Grafika.

Soewandi, E. 2007.Semidang Bukit Kabu. Kepahyang:

Teeuw, A. 2013. Sastra dan Ilmu sastra. Bandung: Pustaka Jaya.

Welllek, Rene dan Austin Werren. 1993. Teori Kesustraan. Terjemahan Melani Budianta. Jakarta: Gramedia. 